\title{
Incognito Hybrid Threats: Avoiding the Alliance's Trident
}

\author{
Frank G. Hoffman
}

NATO is the world's foremost maritime alliance, and the foundations of that alliance, and the economic health and welfare of its members, are tied to the use of global commons and maritime resources more now than ever. ${ }^{1}$ Those interests are being increasingly threatened by covert and indirect forms of aggression from so-called hybrid threats or what in the United States is more often described as "grey-zone" tactics. ${ }^{2}$ These have been defined as actors "employing sequences of gradual steps to secure strategic leverage. The efforts remain below thresholds that would generate a powerful U.S. or international response, but nonetheless are forceful and deliberate, calculated to gain measurable traction over time". ${ }^{3}$ These actions are described by some analysts as a novel form of conflict, and by others as classical "salami-slicing" strategies, fortified with a range of unconventional techniques-from cyberattacks to information campaigns to energy diplomacy. According to senior US officials, "The Gray Zone is characterized by intense political, economic, informational, and military competition more fervent in nature than normal steady-state diplomacy, yet short of conventional war". ${ }^{4}$ Such conflicts "involve some aggression or use of force, but in many ways their defining characteristic is ambiguityabout the ultimate objectives, the participants, whether international

1 Diego A. Ruiz Palmer, "A Maritime Renaissance”, in Joachim Krause and Sebastian Bruns, eds., Routledge Handbook of Naval Strategy and Security (Abingdon: Routledge, 2016), 364.

2 Shota Gvineria, "Euro-Atlantic Security Before and After COVI-19", Journal of Baltic Security, 6, No. 1 (2020), 1-17.

3 On grey-zone concepts, see Michael Mazarr, "Mastering the Gray Zone: Understanding a Changing Era of Conflict", Carlisle, PA: Strategic Studies Institute, December 2015. For a historical conception of the coercive use of force, see Barry Blechman and Stephen A. Kaplan, Force Without War: U.S. Armed Forces as a Political Instrument (Washington, DC: Brookings, 1978). This seminal work was recently updated in Melanie W. Sisson, James A. Siebens and Barry M. Blechman, eds., Military Coercion and US Foreign Policy: The Use of Force Short of War (Abingdon: Routledge, 2020).

4 General Joseph L. Votel, statement before the House Armed Services Committee Subcommittee on Emerging Threats and Capabilities, 18 March, 2015. 
treaties and norms have been violated, and the role that military forces should play in response." 5

Grey-zone tactics and hybrid warfare are an explicit discussion point at NATO and among civilian NATO leaders. ${ }^{6}$

NATO's interpretation of hybrid warfare depicts it as a mixture of military means with non-military tools, including propaganda and cyber activity. To NATO officials, hybrid warfare is "where a wide range of overt and covert military, paramilitary, and civilian measures are employed in a highly integrated design". ${ }^{7}$ This depiction describes a combination of political and unconventional instruments of coercion and influence. These activities entail the coercive use of military force and more subtle forms of malign influence in the political and informational domain. As noted by a former commander of US European Command, the Kremlin's hybrid methods combine an array of diplomatic, economic, information and security tools short of war with Moscow's efforts to undercut the rules of international order. ${ }^{8}$

NATO's interpretation of hybrid threats depicts them as a non-violent mixture of military means with non-military tools, including propaganda and cyber activity. This makes it comparable to grey-zone conflicts, and distinct from this author's version of 2005-2007.9

In addition to NATO's formal awareness, the relevance of the challenge was reinforced by the Strategic Reflection group, which noted the challenges in the future geostrategic environment, including:

5 David Barno and Nora Bensahel, "Fighting and Winning in the 'Gray Zone," War on the Rocks, 19 May, 2015.

6 Anders Fogh Rasmussen, quoted in Mark Landler and Michael Gordon, "NATO Chief Warns of Duplicity by Putin on Ukraine”, New York Times, 8 July, 2014, A1.

7 Wales NATO Summit Communique, 4 September, 2014. http:/www.nato.int/cps/ en/natohq/official_texts_112964.htm?selectedLocale=en.

8 General Philip M. Breedlove, Testimony before the Senate Armed Services Committee, 1 March, 2016.

9 On distinctions in different definitions, see Frank Hoffman, "Examining Complex Forms of Conflict,

Gray Zone and Hybrid Challenges” PRISM, vol. 7, No. 4 (2018), 30-47. On continuity in Russia's approach, see Michael Kofman and Matthew Rojansky. "A Closer Look at Russia's Hybrid War", Kennan Cable No. 7, Washington, DC: Woodrow Wilson Center, April, 2015; Keir Giles, "Russia's 'New' Tools for Confronting the West: Continuity and Innovation in Moscow's Exercise of Power”, (London: Chatham House, March 2016), 5. 
- Both the main challenge of Russia and the emerging challenge of China;

- Incorporating combating terrorism in all its forms and manifestations more fully into the core tasks;

- Reflecting the increasing role of hybrid threats posed by NATO adversaries. ${ }^{10}$

While the group presented these as separate issues, they are all interrelated because Russian and China promote hybrid threats and have been doing so for years. Concerns about Russian coercion via grey-zone/hybrid tactics in Europe have forced NATO to improve the alliance's readiness for rapid response and reassurance measures designed to deter further incursions. However, NATO and other actors overlook the maritime dimension in the region while investing billions in deterring a direct conventional assault from Russia in a coup de main. The alliance lacks recognition of the maritime dimension of the challenge. ${ }^{11}$ As noted by Magnus Nordenman, "The maritime domain is increasingly competitive and contested, and the return of geopolitical competition has important maritime dimensions". ${ }^{12}$

This chapter focuses on this maritime aspect of strategic competition and is structured in three sections. The foregoing first section introduced the topic of hybrid and grey-zone challenges. The second section is the body of the chapter and details past examples and possible future challenges presented by three state actors: Russia, Iran and China. The final section very briefly describes how this challenge will impact NATO's strategy and possibly its organisational approach. Other contributions in this volume address recommendations relevant to sharpening the trident of the alliance's potent maritime forces.

\section{Russia}

Russian preferences for indirect and ambiguous actions including Active Measures and disinformation operations easily fit within the concept of

10 NATO 2030, United for a New Era, Strategic Reflection Group Report, Brussels: NATO, 25 November, 2020, accessed at 201201-Reflection-Group-Final-ReportUni.pdf (nato.int).

11 Franklin D. Kramer and Magnus Nordenman, "A Maritime Framework for the Baltic Sea Region”, (Washington, DC: Atlantic Council, Issue Paper, March 2016).

12 Magnus Nordenman, The Naval Alliance: Preparing NATO for a Maritime Century, (Washington, DC: The Atlantic Council, July 2015). 
grey-zone activities. Some describe Russia's behaviour as reflecting an example of "hybrid warfare". 13

Russian examples of grey-zone/hybrid threats include numerous uses of maritime assets. Regional experts have identified a number of maritime vulnerabilities. ${ }^{14}$ In October 2014, Sweden conducted a major hunt for a foreign submarine, suspected to be Russian, off the coast of Stockholm. The military subsequently confirmed "a mini submarine" had violated its territorial waters. ${ }^{15}$ In March 2015, Russia conducted exercises using a scenario in which it attacked the Swedish island of Gotland, the Danish island of Bornholm and the Finnish Aland Islands. ${ }^{16}$ These exercises have led to the exploration of ways to better defend those islands. In 2016, a Swedish naval exercise detected undersea activity as well. Violations of airspace in the region are almost a daily occurrence. In the same year, a Russian fighter provocatively "buzzed" the American destroyer USS Donald Cook at low altitude when it was operating in the Baltic Sea in April 2016. ${ }^{17}$

During the seizure of the Crimea, the Russian Navy supported the invasion by sinking two of their own ships to block the Ukrainian naval force in Sevastopol from exiting to the Black Sea. This, in effect, permitted the wholesale capture of a sizeable portion of Kyiv's navy. Menacing just outside the 'accidental' blockade was the lethal Moskva missile cruiser. Ukraine lost its naval headquarters and six combat ships.

13 Strategic Survey 2014, The Annual Review of World Affairs (London: Institute for International Strategic Studies, 2014), 53-64; and "Hybrid Warfare: Challenge and Response", Military Balance (London: Institute for International Strategic Studies, 2015), 17-20.

14 Martin Murphy, Frank Hoffman and Gary Schaub Jr., Hybrid Maritime Warfare and the Baltic Sea Region, (Copenhagen, Denmark: University of Copenhagen, Centre for Military Studies, November 2016), 11-19; Gary Schaub Jr., Martin Murphy and Frank Hoffman, "Hybrid Maritime Warfare: Building Baltic Resilience”, RUSI Journal, 162, No. 1 (2017), 32-40.

15 Peter Walker, "Sweden searches for suspected Russian submarine off Stockholm", The Guardian, 19 October, 2014. https:/www.theguardian.com/world/2014/oct/19 /sweden-search-russian-submarine-stockholm; and Elizabeth Braw, "Submarine Intruders on Sweden's Coastline”, World Affairs, Journal, 29 September, 2015. http://www.worldaffairsjournal.org/blog/elisabeth-braw/submarine-intruders-swe den $\%$ E2\%80\%99s-coastline.

16 Wojciech Lorenz and Szymon Zareba, "Aland Islands' Significance to Security in the Baltic Sea Region”, Bulletin No. 72, (Warsaw: Polish Institute of International Affairs, 7 November, 2016).

17 Thomas Gibbons-Neuf, "A Strange Recent History of Russian Jets Buzzing Navy Ships”, Washington Post, 14 April, 2016. 
In another example, on 25 November 2019, Russia seized three Ukrainian naval vessels in the Kerch Strait off the coast of the Crimea, an operation carried out under the direction of the Federal Security Service. Russia used several coastguard ships to fire upon and board Kyiv's ships. The conventional component was supplied by a flight of menacing Su-25 fighters and Ka-52 combat helicopters overhead to enforce the blockade of the Kerch Strait leading into the Sea of Azov. There was little ambiguity in this case and certainly a degree of risk in escalation involved, but the air assets posted nearby were intimidating. Clearly this was more coercive than ambiguous.

As they have done in the Baltic region, the Russians have expressed their displeasure at the increased presence of US Navy ships through unprofessional and dangerous "fly-bys". ${ }^{18}$

The alliance's maritime flanks are exposed to grey-zone/hybrid attacks, especially its private economic infrastructure. The dense networks of commercial shipping, energy transportation nodes and undersea infrastructure require protection. Port security, fishing resources, bridges, underwater cables and other elements of the economic ecosystem of the Baltic Sea are potentially vulnerable targets which must be better secured. ${ }^{19}$ The same can be said for the Black Sea.

The convergence of methods of attack and the targeting of critical commercial or non-military targets inherent in hybrid warfare has not escaped NATO either. As one alliance flag officer noted, "From a maritime perspective we see extensive underwater research programs underway that can lead to disruption of underwater communication cables, we see the use of civilian and merchant vessels for mine laying and obstruction of harbors, and we see civilian fishing vessels carrying SAM threats". ${ }^{20}$ While there is a growing recognition of the need to deflect hybrid threats against NATO members and others, the dense interactions in the Baltic Sea Region create

18 Magnus Nordenman, "Russian Flyby of USS Donald Cook Highlights Tensions in the Baltics", USNI News 15 April, 2016. https://news.usni.org/2016/04/15/russi an-flyby-of-uss-donald-cook-highlights-international-tension-in-the-baltics.

19 Frank Hoffman, "Assessing Baltic Sea Regional Maritime Security”, Foreign Policy Research Institute, Philadelphia Paper, 2017; Gary Schaub and Martin Murphy, "Sea of Peace or Sea of War-Russian Maritime Hybrid Warfare in the Baltic Sea", Naval War College Review 71, No. 2 (2018), 123-147.

20 Rear Admiral Thomas Ernst, German Navy, "Agile Command and Control in a Degraded Environment”, Conference Paper, 4 October, 2016, 18. I am indebted to Dr Gary Schaub for this. 
a target for more unconventional and sophisticated forms of hybrid threats. ${ }^{21}$

The Black Sea is also recognised as a viable contested space, where Russia uses hybrid tactics when overt military action is too costly or risky. 22 Again, as noted by recent assessments, the presence of robust conventional military capabilities underwrites Russia's regional goals. ${ }^{23}$ The potential for violent escalation is usually ever-present in these operations.

Russian Future Capabilities. Russian naval modernisation has focused its rather limited resources on its conventional surface forces and its attack submarines. ${ }^{24}$ This has produced several new classes of ships, many with advanced anti-ship cruise missiles. In addition, Moscow has significantly enhanced its military exclave in the province of Kaliningrad and now Sevastopol. The defensive capabilities in Kaliningrad complicate NATO's responses to crises in the Baltic region. ${ }^{25}$ The build-up in the Crimea gives Russia a dominant position in the Black Sea and enhances its leverage over many smaller countries who use that sea for essential economic activities.

The modernisation of a family of Russian submarines is relevant to this discussion. ${ }^{26}$ Russia concentrates on defending its northern bastions and penetrating the North Atlantic with its attack submarines, which are few

21 Advisory Panel on the NATO Summit 2016, "NATO in a World of Disorder", 1214; and Juliane Smith and Jerry Hendrix, Assured Resolve: Testing Possible Challenges to Baltic Security (Washington, D.C.: Center for a New American Security, 2016), 5 .

22 Nikolas Gvosdev "Russia's Strategy in the Black Sea Basin”, War on the Rocks, 2 August, 2018; Michael Peterson "The Naval Power Shift in the Black Sea”, War on the Rocks, 9 January, 2019; Ben Hodges, Janusz Bugajski, Ray Wojcik and Carsten Schmiedl "One Flank, One Threat, One_Presence", The Center for European Policy Analysis, May 2020; Miruna Sirbu, "Fade to Black, The Black Sea's Strategic Significance", Center for European Policy Analysis, 5 June, 2020.

23 For a comprehensive evaluation, see Steve Flanagan et al., Russia, NATO and Black Sea Security (Santa Monica, CA: RAND 2020).

24 Dmitry Gorenburg, "Russia's Military Modernization Plans: 2018-2027", PONARS Eurasia Policy Memo No. 495, November 2017.

25 Stephan Frühling and Guillaume Lasconjarias, "NATO, A2AD, and the Kaliningrad Challenge", Survival, vol. 58, No. 2 (April/May 2016), 95-116.

26 For an overview and projection of Russian undersea capabilities, see Kathleen $\mathrm{H}$. Hicks, Andrew Metrick, Lisa Sawyer Samp and Kathleen Weinberger, Undersea Warfare in Northern Europe (Washington, DC: Center for Strategic and International Studies, 2016), 8-18. 
in number but quite capable. ${ }^{27}$ This exposes a vulnerability of the alliance. As noted in another study, "NATO and [its] partner nations do not currently possess the ability to quickly counter the Russian undersea challenge in much of the North Atlantic and Baltic Sea". ${ }^{28}$ This disparity can be exploited in grey-zone tactics where non-attribution and deniability are sought.

Russia retains and is building up options with small undersea vessels from its naval special forces that could conduct hybrid warfare. ${ }^{29}$ The designs for Unmanned Underwater Vehicles (UUV) that may deploy missiles, mines and torpedoes make progress continuously. 31 These vessels present the element of surprise, ambiguity and non-attribution that are consistent with Russian grey-zone/hybrid activity. Russia can use these small submersibles for covert infiltration activities or to emplace undersea sensors or compromise undersea communication or energy networks.

„What is clear is that a new generation of leaders, who earned their positions after years within the KGB, is applying long-standing Russian concepts of protracted conflict and full spectrum capabilities." ${ }^{\text {32 }}$

The potential for serious interference in the region has not been overlooked by NATO officials. The Secretary General of NATO has called up-

27 Eric Schmitt, "Russia Bolsters Its Submarine Fleet, and Tensions With U.S. Rise", New York Times, 20 April, 2016. http://www.nytimes.com/2016/04/21/world/europ e/russia-bolsters-submarine-fleet-and-tensions-with-us-rise.html?_r=0; Norm Polmar and Michael Kofman, "Impressive Beneath the Waves", Naval Institute Proceedings, February 2016, 64-65.

28 Hicks et al., Undersea Warfare in Northern Europe, ii.

29 David Manjumdar, “American vs. Russia: The Race for Underwater Spy Drones”, The National Interest, January 2016. http://nationalinterest.org/blog/the-buzz/amer ica-vs-russia-the-race-underwater-spy-drones-14981.

30 Kathleen Weinberger, "Sight Unseen: Russian Auxiliary Submarines and Asymmetric Warfare in the Undersea Domain”, For Your Situational Awareness blog, 31 March, 2016. http://fysa.csis.org/2016/03/31/sight-unseen-russian-auxiliary-submar ines-and-asymmetric-warfare-in-the-undersea-domain/.

31 Sam Bennett, "Unmanned Undersea Vehicles, Russia”, Center for Naval Analyses, 12 November, 2020, slide presentation by author.

32 Oscar Jonsson and Robert Seely, "Russian Full-Spectrum Conflict: An Appraisal after Ukraine”, Journal of Slavic Military Studies, vol. 28, March 2015; Ben Connable, Jason H. Campbell and Dan Madden, Stretching and Exploiting Thresholds for High-Order War (Santa Monica, CA: RAND, 2016); Geoffrey Kirkwood and Dara Massicot, Russian Measures of Influence Short of Force, Santa Monica, CA: RAND, 2020. 
on the members of the alliance to prepare themselves better to counter hybrid threats more effectively. ${ }^{33}$ NATO and European Union governments should redouble their efforts in the Baltic and the Black Sea to counter the Russian arsenal of informational, cyber, economic and hybrid threats. In both theatres, as part of a comprehensive approach, the alliance should focus on an infrastructure protection role in the region. ${ }^{34}$

\section{Hybrid Threats Out of Region}

Another growing concern for the West will be the continued employment of hybrid threats in the Persian Gulf. As noted by Mike Eisenstadt, the Iranian style of war is what they call "non-classic warfare" (jang-e gheir-e kelasik). In non-classic warfare, highly motivated asymmetric forces imbued with revolutionary religious fervour, and comprising large numbers of inexpensive platforms equipped with advanced munitions, create synergies by blending unconventional and conventional operations. ${ }^{35}$ As Brian Michael Jenkins observed, "Iran is a master of hybrid warfare". ${ }^{36}$ The Iranians have mastered hybrid tactics with proxy forces in land campaigns in Lebanon, Iraq and Syria. Iran has used proxies and its own covert operatives to carry out kidnappings and terrorist bombings, sabotage ships at sea and oil facilities on land, and attack embassies and government officials. Scholars describe the most frequently used Iranian strategy as hybrid warfare. ${ }^{37}$

33 Advisory Panel on the NATO Summit 2016, "NATO in a World of Disorder: Making the Alliance Ready for Warsaw", (Washington, D.C.: German Marshall Fund of the United States, March 2016).

34 Steve Horrell, "A NATO Strategy for Security in the Black Sea Region”, Atlantic Council Issue Brief, (September 2016), 5; Neil John Melvin, "Rebuilding Collective Security in the Black Sea Region”, Stockholm, SIPRI, December, 2018.

35 Michael Eisenstadt, "Operating in the Gray Zone, Countering Iran's Asymmetric Way of War", The Washington Institute for Near East Policy, Policy Focus 162 (January 2020). See also Brandon A. Pinkley, Guarding History: The Islamic Revolutionary Guard Corps and the Memory of the Iran-Iraq War, Washington, DC: Joint Chiefs of Staff Joint History Office, Special Historical Study No. 12 (July 2018), 39-41.

36 Brian Michael Jenkins, “An All-Out U.S.-Iran War is Unlikely”, RAND blog, 6 January, 2020, at All-Out U.S.-Iran War Is Unlikely. But Low-Level War Expected to Continue | RAND.

37 Ariane M. Tabatabai No Conquest, No Defeat Iran's National Security Strategy (London, Hurst 2020), 17. 
Iran's hybrid tactics in the maritime domain are well recognised. ${ }^{38}$ Since the days of the Revolution, Teheran has applied a form of "guerrilla warfare at sea" in the Persian Gulf by threatening international trade and oil shipping going back to the so-called Tanker War. ${ }^{39}$ This was the beginning of a campaign in which Iran attacked nearly 200 ships and killed no fewer than 60 sailors. Back then, the United States and its allies had a distinctive conventional superiority over Iran's outdated navy frigates, Silkworm missile batteries and poorly armed small craft. But the IRGC Navy has persistently evolved its tactics and increased its capabilities over the past two decades.

Iran exploits its geographical position along the Gulf, especially its dominant position astride the Strait of Hormuz. At its narrowest point, the strait is only 21 miles wide, and the shipping channel is just 2 miles in each direction, separated by a two-mile buffer lane. Oil tankers carrying crude from Gulf ports have to pass through the strait. Around 18.5 million barrels of crude and refined products move through it annually, about $20 \%$ of all oil produced. That makes the waterway the world's most extremely sensitive energy and commercial choke point. Iran's military doctrine exploits its geopolitical position astride the strait and in the Gulf to leverage its influence. This doctrine applies a hybrid combination of conventional and irregular tactics and weapons to posit a significant anti-access threat to both military and commercial shipping. Closing the narrow seas to all traffic is not in Iran's interests in the long run, but it does give them some geopolitical leverage in crisis management. ${ }^{40}$

The Iranians have two major naval forces. The Iranian Navy (IRIN) is a small conventional force that focuses on the Indian Ocean. The Iranian Revolutionary Guard Corps also contains a maritime force (IRGCN), which is assigned missions that are principally executed inside the Persian

38 My previous examination of malign maritime activities by Iranian forces is in F. G. Hoffman, "Hybrid Threats, Neither Omnipotent nor Unbeatable", Orbis, vol. 54, No. 3 (Summer 2010), 441-455.

39 This section leverages insights by Dr David B. Christ, "Gulf of Conflict A History of U.S.-Iranian Confrontation at Sea”, Washington DC: The Washington Institute for Near East Policy, Policy Focus, June 2009; as well as Craig L. Symonds, Decision at Sea: Five Naval Battles That Shaped American History (New York: Oxford University Press, 2005), 265-320.

40 For a more current assessment of the military considerations involved, see Sidharth Kaushal, "Would Iran Really Try to Close the Strait of Hormuz?", The National Interest, 11 December, 2020. 
Gulf. ${ }^{41}$ It is the latter organisation, built up since the 1980s, that has developed into an agile and distributed maritime force which is hybrid in character and increasingly lethal. ${ }^{42}$ The rough handling of the Iranian Navy in the 1980s accelerated the advent of more sophisticated tactics using fast inshore attack craft (FIAC). The IRGCN is recognised as the foremost "practitioner of small boat 'swarm' tactics that combine speed, mass, coordinated manoeuvre, low radar signature, and concealment". ${ }^{43}$

The doctrine has been demonstrated repeatedly over the past decade. In January 2012, three Revolutionary Guard speedboats harassed the USS New Orleans. The small craft came within 500 yards of the amphibious transport ship as it was transiting the Strait of Hormuz. On the same day, small Iranian boats also harassed the US Coastguard cutter Adak, which was operating east of Kuwait City. ${ }^{44}$ In 2018, a UK flagged oil tanker was seized despite the presence of the UK frigate Montrose. In the summer of 2019, a Japanese-owned oil tanker was mysteriously struck by a mine or missile as it approach the strait, which the United States insisted was a form of Iranian provocation. ${ }^{45}$ In late July 2020, the IRGCN and the Aerospace Force kicked off Iran's fourteenth Great Prophet naval drills (GP-14) by firing ballistic and anti-ship missiles and staging a swarm attack against a mock-up of an American aircraft carrier. ${ }^{46}$ As South Korea recently found out with the seizure of one of its oil tankers in the Gulf by the IRGCN, energy and economic security can be attacked far from home with Iran's irregular approaches. ${ }^{47}$

41 On the structure and basic division of labour between Iran's two naval forces, see U.S. Defense Intelligence Agency, Iranian Military Power: Ensuring Regime Survival and Securing Regional Dominance (Washington, DC, 2019); Office of Naval Intelligence, Iranian Naval Forces: A Tale of Two Navies (Washington, DC, February 2017).

42 Richard Scott, "Surviving the Swarm: Navies Eye New Counters to the FIAC Threat", Jane's Navy International, vol. 199, No. 2 (March 2014), 20-27; Farzin Nadimi, "Iran's Evolving Approach to Asymmetric Naval Warfare: Strategy and Capabilities in the Persian Gulf", The Washington Institute for Near East Policy Policy Focus \#164, April 2020.

43 Scott, 20.

44 Michael Connell, Gulf III: Iran's Power in the Sea Lanes, Washington, DC: United States Institute of Peace (March 2013).

45 Ben Dooley, "Flying Object Struck Tanker in Gulf of Oman, Operator Says, Not a Mine”, New York Times, 14 June, 2019, A1.

46 Farzin Nadimi, Iran Applies Maximum Power to Annual IRGC Naval Exercise", The Washington Institute for Near East Policy Watch, \#3362, 10 August, 2020.

47 Simon Denyer, Min Joo Kim and Erin Cunningham, "Iran: Seizure of S. Korean Tanker is Not Hostage-Taking, Washington Post, 6 January, 2021, A14. 
Capabilities. Iranian military capabilities include a small fleet of frigates, fast patrol craft and a few submarines. It also possesses the world's fourth largest mine inventory, estimated at 5,000 mines, including modern influence mines. The IISS Military Balance credits the Iranians with 56 missile attack craft. ${ }^{48}$ However, recent reports suggest that Iran recently augmented/ modernised that collection in May 2020 with an indigenously produced flotilla of missile boats. ${ }^{49}$ The 600-ton Fateh/Conqueror-class submarine was delivered in February 2019.50 This could reflect a substantial increase in both the endurance and range of the IRIN.

More ominously for the region, the IRGCN has recently commissioned a ship capable of deploying and supporting both small craft and helicopters, giving Iran more range to support operations. ${ }^{51}$ Recent reports suggest that the Iranian Navy will soon field the Abu Mahdi cruise missile, which will expand its anti-ship strike capability to 650 miles, tripling its current range. The IRGCN also recently advertised updates to its shipborne air defence system, one capable of multiple, simultaneous engagements. The IRIN has also announced upgrades to its Ghadir submarines, supposedly improving their surface strike capability and survivability through signature reduction. ${ }^{52}$ The unveiling of what was purported to be an Iranian UUV in May 2020 requires continued observation. ${ }^{53}$

Up until a few years ago, one could scoff at Iranian tactics and conclude that the country's ability to seriously degrade energy shipping and maritime infrastructure was limited. ${ }^{54}$ Iran's indirect but highly destructive attack on the oil production facilities at Abqaiq demonstrate that Teheran is

48 International Institute of Strategic Studies, The Military Balance 2020 (Oxon: Routledge, 2020), 120.

49 Orkhan Jalilov, "Iranian Navy Receives over 100 Missile Boats", Caspian News, 30 May, 2020. https://caspiannews.com/news-detail/iranian-navy-receives-over-100-mi ssile-boats-2020-5-29-30/.

50 https://en.mehrnews.com/news/142565/Fateh-submarine-enjoys-specialized-exclus ive-features-MOD.

51 Jeremy Binnie, "IRGC Navy unveils new base ship", Janes, November, 2020, at IRGC Navy unveils new base ship (janes.com).

52 See the official news agency posts at https:/en.mehrnews.com/news/142826/Ghad ir-submarine-successfully-launches-cruise-missile and https:/en.mehrnews.com/ne ws/163374/Surface-to-surface-missile-fired-from-Ghadir-class-submarine.

53 Iranian official news accounts should be viewed with scepticism. See https://en.m ehrnews.com/news/159263/Iran-gets-admission-into-Uncrewed-Underwater-Vehic le-elite-club.

54 Joshua R. Shifrinson and Miranda Priebe, "A Crude Threat: The Limits of an Iranian Missile Campaign against Saudi Arabian Oil”, International Security 36, No. 1 (Summer 2011), 167-201. 
clearly capable of precision strikes at the region's most critical infrastructure. ${ }^{55}$ Iran appears to want to build on this capability. which will impact Western interests in the Gulf and Western maritime traffic in the Bab al-Mandab strait. ${ }^{56} 57$ NATO must be prepared to address this adaptive and hybrid form of threat in the Gulf, as it is doing in the Baltic and Black Seas.

\section{Chinese Little Blue Men}

NATO has now recognised that it needs to begin thinking about China from a security perspective, which will necessitate that the alliance begins thinking about embracing indirect methods. The last decade manifestly demonstrates that China uses coercive force in innovative ways. "Hybrid warfare has deep historical and cultural roots in China," the Australian scholar Ross Babbage has noted. ${ }^{58}$ Naturally, China's conducting of hybrid operations is culturally adapted to reflect its unique strategic culture and particularly its geostrategic position in the Pacific Ocean. China has been carefully adapting its maritime assets and extending its influence, conducting grey-zone activities with "Chinese characteristics". ${ }^{9}$ China has sought to apply what Chinese General Zhang Zhaozhong described as a "cabbage strategy", one in which China wraps disputed waters in layers of coast-

55 The September 2019 combined cruise missile and drone attacks on the Saudi Aramco's Abqaiq and Khurais oil fields caused extensive damage. Isabel Coles and Dion Nissenbaum, "U.S.-Saudi Pipeline Attacks Originated in Iraq", Wall Street Journal, 28 June, 2019. https:/www.wsj.com/articles/u-s-saudi-pipeline-attacks-ori ginated-from-iraq-11561741133.

56 Afshon Ostovar, “The Grand Strategy of Military Clients: Iran's Way of War”, Security Studies 28, No. 1 (January-March 2019), 183.

57 On Iranian military developments, see DIA Iranian Military Power, 48-56 and 8586; Shahryar Pasandideh, "Under the Radar, Iran's Cruise Missile Capabilities Advance", War on the Rocks, 25 September, 2019.

58 Ross Babbage, Stealing a March: Chinese Hybrid Warfare in the Indo-Pacific, vol. 1 (Washington, DC: Center for Strategic and Budgetary Assessment, 2019), 41-46.

59 For numerous insights, see Andrew S. Erickson and Ryan Martinson, eds., China's Maritime Gray Zone Operations (Annapolis, MD: Naval Institute Press, 2019); Ketian Zhang, "Cautious Bully: Reputation, Resolve, and Beijing's Use of Coercion in the South China Sea”, International Security, vol. 44, No. 1 (Summer 2019), 117-159. 
guard, maritime militia, fishing administration, marine surveillance and its massive fleet of fishing vessels. ${ }^{6061}$

China tends to keep its conventional force in over-watch position in the background, relying on more aggressive use of coastguard/maritime law enforcement vessels when responding to or instigating disputes at sea. ${ }^{62}$ The threat of force is always present since its assets are armed, and the conventional PLA Navy is nearby as a security blanket in the event of escalation and as an escort when Beijing is trying to coerce a nearby state.

China's maritime grey-zone operations represent a challenge for the US and its allies around the globe, not just the South China Sea. In that region, Beijing conducts operations to extend its influence, delegitimise international law and norms, and change the status quo without resorting to war, an approach called “War without Gun Smoke” (一场没有硝烟的战 争) by some sources. ${ }^{63}$ While it is building an impressive grey-hulled navy, it is China's second and third sea forces, the "white-hulled" Coast Guard and "blue-hulled" Maritime Militia, that serve at the front lines of China's maritime strategy in day-to-day operations. The Chinese have weaponised their merchant fleet to advance their national interests, and analysts note that these maritime assets are an armed militia that can engage in crisis situations. ${ }^{64}$ One should not overestimate the effectiveness of this maritime militia, as their poor training, limited platform speed, and unproven command-and-control capabilities limit their contribution. They can, however, complicate crises and congest waterways with raw numbers but have little military functionality. In addition, China deploys more than 800,000 fishing vessels, of which some 4,600 are large distant fishing ships. ${ }^{65}$

60 Michael Beckley, "Balancing China, How to Check Chinese Military Expansion in East Asia”, Belfer Center for Science and International Affairs, Harvard University, Policy Watch, November 2017. https://www.belfercenter.org/publication/bala ncing-china-how-check-chinese-military-expansion-east-asia.

61 For insights into China's coercive activities in the region, see "A Game of Shark and Minnow”, New York Times Magazine, 27 October, 2013. https://www.nytimes. com/newsgraphics/2013/10/27/south-china-sea/index.html.

62 Conor M. Kennedy and Andrew S. Erickson, "Tethered to the PLA: China's Third Sea Force, The People's Armed Forces Maritime Militia", China Maritime Report, No. 1, China Maritime Studies Institute, U.S. Naval War College, March 2017.

63 Andrew S. Erickson and Ryan D. Martinson, China's Maritime Gray Zone Operations (Annapolis, MD: Naval Institute Press, 2019). See also Hunter Stires, "Win Without Fighting", Naval Institute Proceedings, June 2020.

64 Andrew S. Erickson, Statement to the Subcommittee on Seapower and Power Projection Forces of the House Armed Services Committee, 21 September, 2016.

65 Shuxian Luo and Jonathan G. Panter, "China's Maritime Militia and Fishing Fleets”, Military Review (January-February 2021), 7-21. 
Some naval analysts refer to the combined use of these maritime assets as "interagency operations". ${ }^{66}$ The Chinese government has used such operations in the maritime arena. These include hazardous ship handling against the American surveying vessel, USS Impeccable, taking action against Vietnamese fishing and economic zone rights, and a number of measures against the maritime claims and fishing rights of the Philippines. ${ }^{67}$ As noted in the Pentagon's report on China's military power, there is a pattern of activities ranging from "the 2012 Scarborough Reef standoff, the 2014 Haiyang Shiyou-981 oil rig standoff, and a large surge of ships in waters near the Senkakus in 2016". ${ }^{68}$ Beijing, routinely tries to intimidate Hanoi along its coast, and most recently at their major oil extraction site at Vanguard Bank. ${ }^{69}$

China claims its maritime objectives are completely defensive. Certainly, China has energy and resource requirements, and nearly $80 \%$ of its crude oil and the bulk of its global trade passes through the waters of the South China Sea. To secure its interests, however, it is deploying advanced sensors and air defence systems - to artificial islands that provide defensive reach to their airfields and facilities. In 2018, the PLA moved anti-ship cruise missiles and surface-to-air missile systems to three SCS positions in and around the Spratlys, insisting that such moves were purely defensive. ${ }^{70}$ No one should be fooled by these misrepresentations.

66 For insights into Chinese naval modernisation and organisational trends, see Ian Burns McCaslin and Andrew S. Erickson, "The Impacts of Xi-Era Reforms on the Chinese Navy", in Philip C. Saunders et al., eds., Chairman Xi Remakes the PLA: Assessing Chinese Military Reforms, Washington, DC: NDU Press, 2019. On "interagency operations" with the various sea forces, 147-152. For the latest in Chinese naval modernisation, see Ronald O'Rourke, "China Naval Modernization: Implications for U.S. Navy Capabilities”, Washington, DC: Congressional Research Service, 3 December, 2020.

67 For detailed coverage of various past cases, see Michael Green, Kathleen H. Hicks, Zack Cooper, John Schaus and Jake Douglas, "Countering Coercion in Maritime Asia; The Theory and Practice of Gray Zone Deterrence", (Washington, DC: CSIS, May 2017), 52-262.

68 Office of the Secretary of Defense, Military and Security Developments Involving the People's Republic of China 2018 (Washington, DC: Department of Defense, $16 \mathrm{Au}-$ gust, 2018).

69 Trinh Le, "The Vanguard Bank standoff shows China remains undeterred", The Interpreter, Lowy Institute, 6 August, 2019. https://www.lowyinstitute.org/the-inte rpreter/vanguard-bank-standoff-shows-china-remains-undeterred.

70 Oriana Skylar Mastro, Statement before the House Foreign Affairs Committee Subcommittee on Asia, the Pacific, and Non-Proliferation On Chinese Maritime Ambitions China's Maritime Ambitions Implications for U.S. Regional Interests, 
Although these grey-zone/hybrid campaigns are indirect and fall well below the threshold of classical Western concepts of conventional warfare, they do challenge the extant order and the leadership of the United States and its allies. As Babbage summed up:

"[...] it would be a mistake for allied and partner governments to underrate the importance of these Chinese operations. The cumulative effects of the detached and often unfocused U.S. and allied responses to Beijing's hybrid campaigns have been profound. Over the course of decades, the Chinese communist regime has extended its territorial control over large regions of strategic importance, many states and international organizations have been intimidated into acquiescence, and great damage has been done to the credibility of the United States and its allies in the Indo-Pacific." 71

It would also be a mistake not to consider how China's recent appearances in other oceans and its investments in extensive port operations could be exploited in the same way.

In terms of future challenges, the Chinese (like the Russians) are expanding their use of commercial security operations with 20 international PMCs employing over 3,000 personnel. ${ }^{72}$ One can expect that as the Belt and Road Initiative evolves and the Chinese acquire broader economic interests, they will need to protect these in some way. ${ }^{73}$ Undersea security, either in surveillance or military applications, may also emerge in hybrid scenarios. Like the United States and Russia, China is pursuing unmanned undersea systems, which could be employed in non-conventional conflict

30 June, 2020, 4. Can be accessed at HHRG-116-FA05-Wstate-MastroO-20200630. pdf (house.gov).

71 Babbage, 3.

72 Fatoumta Dialio, "Private Security Companies: The New Notch in Beijing's Belt and Road Initiative?", Stockholm, Sweden, Institute for Security and Development Policy, 5 June, 2018; Alessandro Arduino, "China's Private Security Companies: The Evolution of a New Security Actor", Washington, DC, NBR Special Report \#80 (September 2019).

73 "Guarding the Silk Road, How China's Private Security Companies are Going Global”, World Economic Forum, 24 October, 2018. https:/www.weforum.org/a genda/2018/10/guarding-the-silk-road-how-chinas-private-security- companies-aregoing-global; Sergey Sukhankin, "Chinese Private Security Contractors: New Trends and Future Prospects”, China Brief, vol. 20, No. 9 (15 May, 2020). https://ja mestown.org/program/chinese-private-security-contractors-new-trends-and-futureprospects/. 
settings. ${ }^{74}$ Indonesia collected three, presumably, Chinese undersea drones in its waters near Selayar Island in late December 2020.75

Thus, alliance maritime interests, including sustaining international law and having access to key resources around the globe, are at risk. "As evidenced by their hybrid operations in the South and East China Seas...," some analysts conclude, "PRC leaders are clearly pursuing more complex and less-escalatory paths" to confront the West and undermine the current international order. ${ }^{76}$ Since NATO recognised China as part of its growing and expanded agenda, China has behoved the alliance to ensure it understands the PLAN and the other layers to China's maritime coercion.

\section{Assessment}

To sum up, several powers are contesting international law and norms that the alliance benefits from, and the maritime domain is a part of this contest. Each of these three challengers will apply indirect modes of conflict in distinctive ways, but their multi-modal combinations are not novel and can be countered. However, the alliance is not yet prepared, strategically or organisationally, to respond.

Addressing hybrid threats and modes of coercion facing the West requires a holistic appreciation of the challenges, and a strategy that gives appropriate weight to the alliance's maritime vulnerabilities. ${ }^{77} \mathrm{Up}$ to this point, initiatives like the European Defense Initiative lacked a substantial maritime dimension. Senior NATO officials are clear that the alliance

74 Kelvin Wong, “China's Unmanned Maritime Vehicle Development, Present and Future”, Jane's Defence Systems, 12 November, 2020, slide presentation by author.

75 Kristin Huang, "China's underwater drones seized in Indonesia expose tech, routes and potential submarine plans”, South China Morning Post, January 2021. https:/www.scmp.com/news/china/military/article/3117076/chinas-underwater-dr ones-seized-indonesia-expose-tech-routes.; H. I. Sutton, "Chinese Survey Ship Caught 'Running Dark' Give Clues to Underwater Drone Operations”, USNI News, 16 January, 2021. https://news.usni.org/2021/01/16/chinese-survey-ship-cau ght-running-dark-give-clues-to-underwater-drone-operations.

76 Bryan Clark, "The Navy Should Make Hard Choices to Implement its New Strategy”, Aerospace \& Defense, 27 December, 2020.

77 Ine Eriksen Soreide, "NATO and the North Atlantic: Revitalizing Collective Defense and the Maritime Domain”, PRISM, vol. 6, No. 2 (2016), 49-57; and Anna Wieslander, NATO, the U.S. and Baltic Sea Security, (Stockholm: Swedish Institute of International Affairs, Ulpaper No. 3, 2016). 
must improve its deterrence posture and improve the territorial defence of member states. ${ }^{78}$ To do so, it must place more weight on addressing the growing maritime challenge, including that beyond its most immediate waters. Responding to maritime conflicts short of high-intensity conventional war requires the sort of government approaches espoused for the stability campaigns of South Asia and the Middle East. ${ }^{79}$ The concept of "Total Defence" developed in the Nordic region to address vulnerabilities can be expanded to address possible gaps in maritime security and ensure the economic interests of the region. ${ }^{80}$

Policymakers recognise that an updated Alliance Maritime Strategy (AMS) is needed. ${ }^{81}$ The AMS should seek to incorporate the full nature of challenges facing members from a maritime security perspective, not just conventional military threats ashore. The priority for NATO's naval forces should be aligned towards deterring major aggression, but an era of strategic competition requires greater breadth, with attention placed on the undermining of maritime security short of overt warfare. China no doubt will continue to enhance the PLA-Navy into a powerful instrument over time. But for now, there is more to war than conventional battles, and it is more politically and economically important to leave maritime security just to admirals. ${ }^{82}$ NATO is encouraged to work with the EU and critical stakeholders like the private sector/commercial institutions. As the US Department of the Navy's latest maritime strategy notes, "Forward naval forces, leveraging our complementary law-enforcement authorities and military capabilities, will stand ready to disrupt malign activities through

78 Philip M. Breedlove, "NATO's Next Act: How to Handle Russia and Other Threats", Foreign Affairs, (July/August 2016), 100.

79 Shawn Lansing, "A White Hull Approach to Taming the Dragon: Using the Coast Guard to Counter China”, War on the Rocks, 22 February, 2018; Patrick M. Cronin and Hunter Stires, "China is Waging a Maritime Insurgency in the South China Sea”, National Interest, 6 August, 2018; Walker Mills, "White Ships for Gray Zones”, Naval Institute Proceedings, February 2020. The latter accessed at https://w ww.usni.org/magazines/proceedings/2020/february/white-ships-gray-zone.

80 Hakon Lunde Saxi, Bengt Sundelius and Brett Swaney, "Baltics Left of Bang: Nordic Total Defense and Implications for the Baltic Sea Region”, Washington, DC: Institute for National Strategic Studies, Strategic Forum \#304, January 2020.

81 Nordenman, "Updating NATO’s Maritime Strategy", 12-13; and Nordenman, "From Submarines to Smuggler Skiffs", 59.

82 Jonathan D. Caverley and Peter Dombrowski, "Too Important to Be Left to the Admirals: The Need to Study Maritime Great-Power Competition”, Security Studies, 29, No. 4, 2020, 579-600. 
assertive operations". ${ }^{83}$ The alliance's strategy must be prepared to do the same.

A maritime strategy may also require organisational transformation as well as conceptual adaptation. As Admiral James Stavridis noted a few years ago, it is time for a collective "response to hybrid warfare at sea, which may require developing new tactics and technologies, working closely with allies and partners" ${ }^{84}$ It may also require new partnerships and organisations. Standing maritime security task forces that provide port and infrastructure security, domain awareness and law enforcement capabilities in key regions are one potential solution. ${ }^{85}$

\section{Conclusion}

The relevance of the sea will rise in the $21^{\text {st }}$ century ${ }^{86}$; so will indirect challenges to the use of the maritime domain. Today, the alliance is stronger than it was in 2014 in so many respects. Yet, it remains underprepared for maritime versions of hybrid conflict. By whatever name one wants to call it, "Hybrid warfare is coming to a theater of war near you," as Admiral Stavridis concluded. ${ }^{87}$ The question is not "if" but when, and where or in what theatre, future actors will seek to evade the alliance's trident.

\section{Works cited}

Arduino, Alessandro. "China's Private Security Companies: The Evolution of a New Security Actor", Washington, DC, NBR Special Report \#80, September 2019.

Babbage, Ross. Stealing a March: Chinese Hybrid Warfare in the Indo-Pacific, vol. 1 (Washington, DC: Center for Strategic and Budgetary Assessment, 2019), 41-46.

83 Secretary of the Navy, Kenneth J. Braithwaite et al., Advantage at Sea: Prevailing with Integrated All-Domain Naval Power (Washington, D.C.: U.S. Navy, U.S. Marine Corps, and U.S. Coast Guard, 17 December, 2020).

84 Admiral James Stavridis, U.S. Navy (ret.), "Hybrid Maritime Warfare is Coming", Naval Institute Proceedings (December 2016), 34.

85 Eric Sayers, "Time to Launch a Combined Maritime Task Force for the Pacific", War on the Rocks, 1 June, 2018.

86 Geoffrey Till, Seapower A Guide for the Twenty-First Century (New York: Routledge, 2013), 339.

87 Stavridis, 33 . 
Barno, David and Nora Bensahel. "Fighting and Winning in the 'Gray Zone", War on the Rocks, 19 May, 2015.

Beckley, Michael. "Balancing China, How to Check Chinese Military Expansion in East Asia”, Belfer Center for Science and International Affairs, Harvard University, Policy Watch, November 2017.

Bennett, Sam. "Unmanned Undersea Vehicles, Russia”, Center for Naval Analyses, 12 November, 2020, slide presentation from author.

Binnie, Jeremy. "IRGC Navy unveils new base ship", Janes, November, 2020, at IRGC Navy unveils new base ship (janes.com)

Blechman, Barry and Stephen A. Kaplan. Force Without War: U.S. Armed Forces as a Political Instrument (Washington, DC: Brookings, 1978).

Braithwaite, Kenneth J. et al. Advantage at Sea: Prevailing with Integrated All-Domain Naval Power (Washington, D.C.: U.S. Navy, U.S. Marine Corps, and U.S. Coast Guard, 17 December, 2020).

Braw, Elizabeth. “Submarine Intruders on Sweden's Coastline”, World Affairs, Journal, 29 September, 2015.

Breedlove, Philip M. "NATO's Next Act: How to Handle Russia and Other Threats", Foreign Affairs, (July/August 2016), 100.

Breedlove, Philip M. Testimony before the Senate Armed Services Committee, 1 March, 2016.

Caverley, Jonathan D. and Peter Dombrowski. "Too Important to Be Left to the Admirals: The Need to Study Maritime Great-Power Competition", Security Studies, 29, No. 4 2020, 579-600.

Christ, David B. "Gulf of Conflict A History of U.S.-Iranian Confrontation at Sea", Washington DC: The Washington Institute for Near East Policy, Policy Focus, June 2009.

Clark, Bryan. "The Navy Should Make Hard Choices to Implement its New Strategy”, Aerospace \& Defense, 27 December, 2020.

Coles, Isabel and Dion Nissenbaum. "U.S.-Saudi Pipeline Attacks Originated in Iraq”, Wall Street Journal, 28 June, 2019, accessed at https://www.wsj.com/article s/u-s-saudi-pipeline-attacks-originated-from-iraq-11561741133.

Connell, Michael. Gulf III: Iran's Power in the Sea Lanes, Washington, DC: United States Institute of Peace (March 2013).

Connable, Ben, Jason H. Campbell and Dan Madden. Stretching and Exploiting Thresholds for High-Order War (Santa Monica, CA: RAND, 2016).

Cronin, Patrick M. and Hunter Stires. "China is Waging a Maritime Insurgency in the South China Sea”, National Interest, 6 August, 2018.

Dialio, Fatoumta. "Private Security Companies: The New Notch in Beijing's Belt and Road Initiative?", Stockholm, Sweden, Institute for Security and Development Policy, 5 June, 2018.

Denyer, Simon, Min Joo Kim and Erin Cunningham. "Iran: Seizure of S. Korean Tanker is Not Hostage-Taking”, Washington Post, 6 January, 2021, A14. 
Dooley Ben. "Flying Object Struck Tanker in Gulf of Oman, Operator Says, Not a Mine”, New York Times, 14 June, 2019, A1.

Eisenstadt, Michael. “Operating in the Gray Zone, Countering Iran's Asymmetric Way of War”, The Washington Institute for Near East Policy, Policy Focus 162 (January 2020).

Erickson, Andrew S. Statement to the Subcommittee on Seapower and Power Projection Forces of the House Armed Services Committee, 21 September, 2016.

Flanagan, Steve et al. Russia, NATO and Black Sea Security (Santa Monica, CA: RAND 2020).

Frühling, Stephan and Guillaume Lasconjarias. "NATO, A2AD, and the Kaliningrad Challenge”, Survival, vol. 58, No. 2 (April/May 2016), 95-116.

Gibbons-Neuf, Thomas. "A Strange Recent History of Russian Jets Buzzing Navy Ships”, Washington Post, 14 April, 2016.

Giles, Keir. "Russia's 'New' Tools for Confronting the West: Continuity and Innovation in Moscow's Exercise of Power", (London: Chatham House, March 2016), 5 .

Gorenburg, Dmitry. "Russia’s Military Modernization Plans: 2018-2027", PONARS Eurasia Policy Memo No. 495, November 2017.

Green, Michael, Kathleen H. Hicks, Zack Cooper, John Schaus and Jake Douglas. "Countering Coercion in Maritime Asia; The Theory and Practice of Gray Zone Deterrence”, (Washington, DC: CSIS, May 2017), 52-262.

Gvineria, Shota. "Euro-Atlantic Security Before and After COVI-19", Journal of Baltic Security, 6, No. 1 (2020), 1-17.

Gvosdev Nikolas. "Russia’s Strategy in the Black Sea Basin”, War on the Rocks, 2 August, 2018.

Hicks, Kathleen H., Andrew Metrick, Lisa Sawyer Samp and Kathleen Weinberger. Undersea Warfare in Northern Europe (Washington, DC: Center for Strategic and International Studies, 2016), 8-18.

Hodges, Ben, Janusz Bugajski, Ray Wojcik and Carsten Schmiedl. "One Flank, One Threat, One_Presence”, The Center for European Policy Analysis, May 2020.

Hoffman, Frank. "Hybrid Threats, Neither Omnipotent nor Unbeatable", Orbis, vol. 54, No. 3 (Summer 2010), 441-455.

Hoffman, Franck. "Examining Complex Forms of Conflict, Gray Zone and Hybrid Challenges", PRISM, vol. 7, No. 4. (2018), 30-47.

Hoffman, Frank. “Assessing Baltic Sea Regional Maritime Security”, Foreign Policy Research Institute, Philadelphia Paper, 2017.

Horrell Steve. "A NATO Strategy for Security in the Black Sea Region”, Atlantic Council Issue Brief, (September 2016), 5.

Huang, Kristin. “China's underwater drones seized in Indonesia expose tech, routes and potential submarine plans”, South China Morning Post, January 2021.

IISS. Strategic Survey 2014, The Annual Review of World Affairs (London: Institute for International Strategic Studies, 2014), 53-64. 
IISS. "Hybrid Warfare: Challenge and Response", Military Balance (London: Institute for International Strategic Studies, 2015), 17-20.

IISS. The Military Balance 2020 (Oxon: Routledge, 2020), 120.

Jalilov, Orkhan. "Iranian Navy Receives over 100 Missile Boats", Caspian News, 30 May, 2020, accessed at https://caspiannews.com/news-detail/iranian-navy-receive s-over-100-missile-boats-2020-5-29-30/

Jenkins, Brian Michael. “An All-Out U.S.-Iran War is Unlikely”, RAND blog, 6 January, 2020.

Jonsson, Oscar and Robert Seely. "Russian Full-Spectrum Conflict: An Appraisal after Ukraine”, Journal of Slavic Military Studies, vol. 28, March 2015.

Kaushal, Sidharth. "Would Iran Really Try to Close the Strait of Hormuz?", The National Interest, 11 December, 2020.

Kennedy, Conor M. and Andrew S. Erickson. "Tethered to the PLA: China's Third Sea Force, The People's Armed Forces Maritime Militia”, China Maritime Report, No. 1, China Maritime Studies Institute, U.S. Naval War College, March 2017.

Kirkwood, Geoffrey and Dara Massicot. Russian Measures of Influence Short of Force, Santa Monica, CA: RAND, 2020.

Kofman, Michael and Matthew Rojansky. "A Closer Look at Russia's Hybrid War", Kennan Cable No. 7, Washington, DC: Woodrow Wilson Center, April 2015.

Kramer, Franklin D. and Magnus Nordenman. "A Maritime Framework for the Baltic Sea Region”, (Washington, D.C.: Atlantic Council, Issue Paper, March 2016).

Landler, Mark and Michael Gordon. "NATO Chief Warns of Duplicity by Putin on Ukraine”, New York Times, 8 July, 2014, A1.

Lansing, Shawn. "A White Hull Approach to Taming the Dragon: Using the Coast Guard to Counter China”. War on the Rocks, 22 February, 2018.

Le, Trinh. "The Vanguard Bank standoff shows China remains undeterred", The Interpreter, Lowy Institute, 6 August, 2019.

Lorenz, Wojciech and Szymon Zareba. "Aland Islands' Significance to Security in the Baltic Sea Region”, Bulletin No. 72, (Warsaw: Polish Institute of International Affairs, 7 November, 2016).

Luo, Shuxian and Jonathan G. Panter. "China's Maritime Militia and Fishing Fleets”, Military Review (January-February 2021), 7-21.

Manjumdar, David. “American vs. Russia: The Race for Underwater Spy Drones”, The National Interest, January 2016.

Mastro, Oriana Skylar. Statement before the House Foreign Affairs Committee Subcommittee on Asia, the Pacific, and Non-Proliferation On Chinese Maritime Ambitions China's Maritime Ambitions Implications for U.S. Regional Interests, 30 June, 2020, 4. HHRG-116-FA05-Wstate-MastroO-20200630.pdf (house.gov).

Martinson, Ryan. China's Maritime Gray Zone Operations (Annapolis, MD: Naval Institute Press, 2019). 
Mazarr, Michael. "Mastering the Gray Zone: Understandnig a Changing Era of Conflict”, Carlisle, PA: Strategic Studies Institute, December 2015.

McCaslin, Ian Burns and Andrew S. Erickson. "The Impacts of Xi-Era Reforms on the Chinese Navy", in Phillip C. Saunders et al., eds., Chairman Xi Remakes the PLA: Assessing Chinese Military Reforms, Washington, DC: NDU Press, 2019.

Melvin, Neil John. "Rebuilding Collective Security in the Black Sea Region", Stockholm, SIPRI, December 2018.

Mills, Walker. "White Ships for Gray Zones”, Naval Institute Proceedings, February 2020.

Murphy, Martin, Frank Hoffman and Gary Schaub Jr. Hybrid Maritime Warfare and the Baltic Sea Region, (Copenhagen, Denmark: University of Copenhagen, Centre for Military Studies, November 2016).

Nadimi, Farzin. "Iran's Evolving Approach to Asymmetric Naval Warfare: Strategy and Capabilities in the Persian Gulf", The Washington Institute for Near East Policy, Policy Focus \#164, April 2020.

Nadimi, Farzin. "Iran Applies Maximum Power to Annual IRGC Naval Exercise”, The Washington Institute for Near East Policy Watch, \#3362, 10 August, 2020.

Nordenman, Magnus. The Naval Alliance: Preparing NATO for a Maritime Century, (Washington, D.C.: The Atlantic Council, July 2015).

Nordenman, Magnus. "Russian Flyby of USS Donald Cook Highlights Tensions in the Baltics”, USNI News, 15 April, 2016, at https://news.usni.org/2016/04/15/rus sian-flyby-of-uss-donald-cook-highlights-international-tension-in-the-baltics.

NATO 2030, United for a New Era, Strategic Reflection Group Report, Brussels: NATO, 25 November, 2020.

O’Rourke, Ronald. “China Naval Modernization: Implications for U.S. Navy Capabilities”, Washington, DC: Congressional Research Service, 3 December, 2020.

Ostovar, Afshon. "The Grand Strategy of Military Clients: Iran's Way of War”, Security Studies, 28, No. 1 (January-March 2019).

Palmer, Diego A. Ruiz. "A Maritime Renaissance", in Joachim Krause and Sebastian Bruns, eds., Routledge Handbook of Naval Strategy and Security (Abingdon: Routledge, 2016).

Pasandideh, Shahryar. "Under the Radar, Iran's Cruise Missile Capabilities Advance", War on the Rocks, 25 September, 2019.

Pinkley, Brandon A. Guarding History: The Islamic Revolutionary Guard Corps and the Memory of the Iran-Iraq War, Washington, DC: Joint Chiefs of Staff Joint History Office, Special Historical Study No. 12 (July 2018), 39-41.

Peterson, Michael. "The Naval Power Shift in the Black Sea", War on the Rocks, 9 January, 2019.

Polmar, Norm and Michael Kofman. "Impressive Beneath the Waves", Naval Institute Proceedings, February 2016, 64-65.

Schaub, Gary, Martin Murphy and Frank Hoffman. "Hybrid Maritime Warfare: Building Baltic Resilience”, RUSI Journal, 162, No. 1 (2017), 32-40. 
Schaub, Gary and Martin Murphy. "Sea of Peace or Sea of War-Russian Maritime Hybrid Warfare in the Baltic Sea", Naval War College Review 71, No. 2 (2018), 123-147.

Sayers, Eric. "Time to Launch a Combined Maritime Task Force for the Pacific", War on the Rocks, 1 June, 2018.

Saxi, Hakon Lunde, Bengt Sundelius and Brett Swaney. "Baltics Left of Bang: Nordic Total Defense and Implications for the Baltic Sea Region”, Washington, DC: Institute for National Strategic Studies, Strategic Forum \#304, January 2020.

Schmitt, Eric. "Russia Bolsters Its Submarine Fleet, and Tensions With U.S. Rise”, New York Times, 20 April, 2016.

Scott, Richard. "Surviving the Swarm: Navies Eye New Counters to the FIAC Threat", Jane's Navy International, vol. 199, No. 2 (March 2014), 20-27.

Shifrinson, Joshua R. and Miranda Priebe. "A Crude Threat: The Limits of an Iranian Missile Campaign against Saudi Arabian Oil”, International Security, 36, No. 1 (Summer 2011), 167-201.

Sisson, Melanie W., James A. Siebens and Barry M. Blechman, eds. Military Coercion and US Foreign Policy: The Use of Force Short of War (Abingdon: Routledge, 2020).

Sirbu, Miruna. "Fade to Black, The Black Sea's Strategic Significance”, Center for European Policy Analysis, 5 June, 2020.

Smith, Juliane and Jerry Hendrix. Assured Resolve: Testing Possible Challenges to Baltic Security (Washington, D.C.: Center for a New American Security, 2016).

Soreide, Ine Eriksen. "NATO and the North Atlantic: Revitalizing Collective Defense and the Maritime Domain”, PRISM, vol. 6, No. 2 (2016), 49-57.

Stavridis, James. "Hybrid Maritime Warfare is Coming”, Naval Institute Proceedings (December, 2016).

Stires, Hunter. "Win Without Fighting”, Naval Institute Proceedings, June 2020.

Sukhankin,Sergey. "Chinese Private Security Contractors: New Trends and Future Prospects”, China Brief, vol. 20, No. 9 (15 May, 2020).

Sutton, H. I. "Chinese Survey Ship Caught 'Running Dark' Give Clues to Underwater Drone Operations”, USNI News, 16 January, 2021, at https://news.usni.or g/2021/01/16/chinese-survey-ship-caught-running-dark-give-clues-to-underwaterdrone-operations.

Symonds, Craig L. Decision at Sea: Five Naval Battles That Shaped American History (New York: Oxford University Press, 2005), 265-320.

Tabatabai, Ariane M. No Conquest, No Defeat Iran's National Security Strategy (London, Hurst 2020).

Till, Geoffrey. Seapower A Guide for the Twenty-First Century (New York: Routledge, 2013).

U.S. Navy. Iranian Naval Forces: A Tale of Two Navies (Washington, DC, Office of Naval Intelligence February 2017). 
U.S. Department of Defense. Military and Security Developments Involving the People's Republic of China 2018 (Washington, DC: Department of Defense, 16 August, 2018).

U.S. Defense Intelligence Agency. Iranian Military Power: Ensuring Regime Survival and Securing Regional Dominance (Washington, DC, 2019).

Votel, Joseph L. Statement before the House Armed Services Committee Subcommittee on Emerging Threats and Capabilities, 18 March, 2015.

Walker, Peter. "Sweden searches for suspected Russian submarine off Stockholm", The Guardian, 19 October, 2014.

Wales NATO Summit Communique, 4 September, 2014, at http://www.nato.int/cp s/en/natohq/official_texts_112964.htm?selectedLocale=en.

Weinberger, Kathleen. "Sight Unseen: Russian Auxiliary Submarines and Asymmetric Warfare in the Undersea Domain”, For Your Situational Awareness blog, 31 March, 2016, at http://fysa.csis.org/2016/03/31/sight-unseen-russian-auxiliary-s ubmarines-and-asymmetric-warfare-in-the-undersea-domain/.

Wieslander, Anna. NATO, the U.S. and Baltic Sea Security, (Stockholm: Swedish Institute of International Affairs, Ulpaper No. 3, 2016).

Wong, Kelvin. “China's Unmanned Maritime Vehicle Development, Present and Future”, Jane's Defence Systems, 12 November, 2020, slide presentation by author.

World Economic Forum, "Guarding the Silk Road, How China's Private Security Companies are Going Global”, Davos, 24 October, 2018.

Zhang, Ketian. "Cautious Bully: Reputation, Resolve, and Beijing's Use of Coercion in the South China Sea”, International Security, vol. 44, No. 1 (Summer 2019), 117-159, 